\title{
Research on Case Teaching Method of Database System Based on Pragmatism Educational Thought
}

\author{
Shicheng Hu${ }^{1}$, Song Wang1, Yang $\mathrm{Liu}^{2 *}$ \\ ${ }^{1}$ School of Economics \& Management, Harbin Institute of Technology, Harbin, China \\ ${ }^{2}$ School of Computer Science \& Technology, Harbin Institute of Technology, Harbin, China \\ Email: *lyyang@hit.edu.cn
}

How to cite this paper: Hu, S. C., Wang, S., \& Liu, Y. (2020). Research on Case Teaching Method of Database System Based on Pragmatism Educational Thought. Open Journal of Social Sciences, 8, 405-412. https://doi.org/10.4236/jss.2020.87033

Received: June 27, 2020 Accepted: July 28, 2020 Published: July 31, 2020

\begin{abstract}
This paper, guided by pragmatism education thought and combined with the characteristics of "database system" course, constructs a teaching model based on case teaching method. We put forward a more effective supporting system model, and uses rich teaching methods. It means to make the whole teaching link more perfect and reasonable. Practice shows that this teaching method not only improves students' theoretical level and practical operation ability, but also greatly arouses students' enthusiasm.
\end{abstract}

\section{Keywords}

Database System, Teaching Method, Pragmatism, Case Teaching

\section{Introduction}

With the rapid development of information technology, database technology is increasingly playing an important role in many areas including traditional data processing, information management, transaction processing, artificial intelligence, search engine, office automation systems in all walks of life, various network application systems, cloud computing and some other emerging fields. Therefore, courses related to database technology have become compulsory courses for computer majors in colleges and universities. "Database system" (Wang \& Sa, 2018) focuses on practical applications with strong theoretical and practical meanings. In modern computer software technology, database system knowledge has become an important content to support the development of software technology. Thus, in the teaching process of database system, we should not only enable students to master profound theoretical knowledge, but also focus on cultivating students' practical ability. 
Along with the continuous development of database system course teaching, many teachers are actively exploring new and effective teaching methods. At present, the research of database teaching method is mainly divided into the following aspects. 1) Case-based pedagogy. For example, Wan (2016) put forward to apply case method to the teaching mode of database application course in higher vocational colleges according to the practice of database application teaching and combining with specific teaching cases. The analysis of specific cases has advantages in stimulating students' interest and initiative in learning. Qian \& $\mathrm{Wu}(2016)$ analyzed the problems existing in the teaching of non-computer major data courses, combined with practical teaching experience, and introduced case teaching into the teaching process of database. 2) Task-based teaching method. Under the guidance of constructivist learning theory and task-driven teaching thought, $\mathrm{Wu}$ (2016) explored the use of task-driven teaching mode in database teaching. In the teaching process, the students' habits of independent learning and cooperative learning are cultivated through the steps of task proposal, analysis, realization and evaluation, so as to improve the teaching effect. $\mathrm{Li}$ (2017) adopted a task-driven teaching method for all contents of the database system, enabling students to independently design a relatively complete database application system. 3) Action-oriented pedagogy. Li (2016) discussed the feasibility of using action-oriented teaching method in database teaching, and illustrated the implementation process, common methods of action-oriented teaching and possible problems in teaching with examples.

These teaching methods are helpful to improve students' ability to use the database. However, there is still a need for further improvement in the teaching of "database system" in the following aspects; 1) Construct a more scientific teaching mode of database system; 2) Propose a more effective model of teaching support system; 3) Use more abundant teaching methods and means to further improve students' learning initiative and creativity. Therefore, based on the pragmatic educational thought, this paper studies the teaching method of "database system" from these aspects by using case method.

\section{Research on Teaching Mode of "Database System"}

As "database system" is a practical course, we propose a teaching method of "database system" based on the pragmatic educational thought. Pragmatism education thought is a kind of educational theory produced on the basis of pragmatism philosophy, whose typical representative is the famous American educator John Dewey. The main points of pragmatism education thought are as follows: 1) It criticize traditional educational theories ignoring the changing needs of students' personality and social life. 2) It holds that education is life, education is the continuous transformation of experience, and school is the society. 3) Pragmatism education thought emphasizes student-centered education and criticizes the focus of old education on teachers and textbooks. It holds that students are the center of education, and teachers serve a function: They organize and guide students' activities according to students' characteristics and needs. 
4) It pays attention to students' experience, interest and needs, and emphasize the initiative and creativity of students' development and the student-centered teaching practice, that is, learning by doing. 5) It takes for the process of education is a process in which teachers and students participate in and cooperate with each other. It advocates equality between teachers and students. Based on the pragmatic educational thought, we construct a teaching mode of "database system", as shown in Figure 1.

In this teaching mode, guided by pragmatism teaching thought, the method of case teaching is adopted in concrete practice. In the process of teaching, teachers use demonstrative teaching and research-based teaching, while students use autonomous learning and collaborative learning.

Case teaching method is a case-based teaching method. Teachers play the role of designers and motivators in teaching and encourage students to actively participate in discussions. According to the needs of curriculum teaching objectives and teaching contents, teachers set specific teaching cases to guide students to participate in analysis and discussion, and let students actively think and explore in specific problem situations, so as to cultivate students' comprehensive ability (Wan, 2016). We divide it into two levels: teachers and students.

\subsection{Teachers' Level}

\section{1) Demonstrative Teaching}

In the process of teaching, teachers enable students to acquire knowledge and skills by demonstration and explanation. In the demonstration teaching, teachers demonstrate the contents of the database taught on the spot, operating while explaining, stressing the key steps and matters needing attention. Demonstrative teaching realizes teacher-student interaction. For example, when teaching SQL language, teachers demonstrate different sentence structure and produce different results, even if they are slightly different. By doing so, it can deepen students' understanding and improve students' interest and efficiency.

\section{2) Research Teaching}

Research-based teaching means that in the course of teaching, students are required to learn independently and deeply through the learning style characterized by "independent, inquiry and cooperative" under the guidance of teachers. In this way, the cognitive objectives in the curriculum standards can be better achieved. Research-based teaching method is a comprehensive teaching method to train students' research ability and improve teachers' research level.

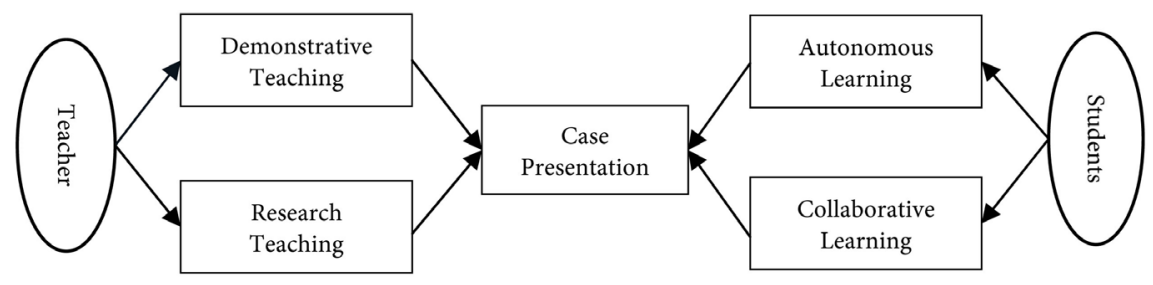

Figure 1. Teaching model of database system. 
Teachers need to carry out scientific design for specific chapters from the current teaching situation of database courses, and establish corresponding research-based teaching models of database courses.

\subsection{Students' Level}

\section{1) Autonomous Learning}

In order to fully expand students' horizons, cultivate students' learning habits, autonomous learning ability and exercise students' comprehensive quality, students are usually given questions or some problems they encounter. Students are asked to use resources such as the Internet to find answers, propose measures to solve problems, and then put forward discussions and evaluations. It is a valuable method to use autonomous learning method to learn database knowledge.

\section{2) Collaborative Learning}

The purpose of "collaborative learning" is to change the traditional teaching mode of "teachers speak and students listen", so as to stimulate students' interest in learning, strengthen the cultivation of students' consciousness of innovation, teamwork and creativity, and make students learn to cooperate with others and be good at communicating with others. In practical application, every well-run large database cannot be completed by one person's strength, it requires collaboration, overall planning, joint efforts to achieve a good database system. Therefore, in the teaching process of database, it is necessary to cultivate students' sense of team spirit and cooperation.

\section{Model of "Database System" Support System}

Database system is a subject with strong theory and application. So in order to better master database knowledge, we should not only have a solid theoretical foundation, but also have a strong practical operation ability. Based on this, we construct the supporting system model of database system. As shown in Figure 2.

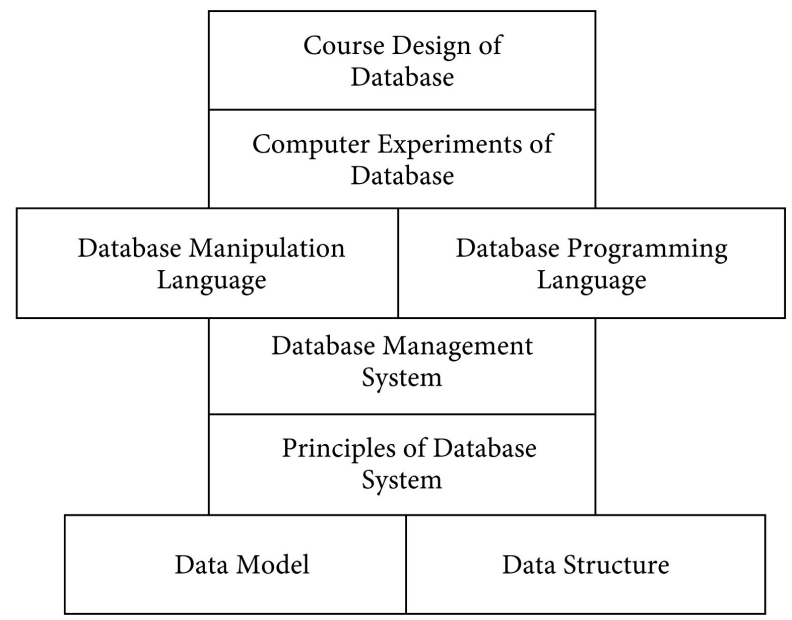

Figure 2. Database system support model. 
In order to realize the real database application system, students must master the solid basic knowledge of database system and the ability of database computer practice. Through a profound understanding of the basic concepts, principles, methods and applications of the database system, students will acquire rich knowledge of the database system. For instance, it is necessary to understand and master the basic knowledge of database (including the development of database technology, data model, database architecture, etc.; relational data model, database query language SQL, function dependency and relational normalization theory); database management system implementation technology (concepts such as transaction, concurrency control, recovery, integrity and security and related implementation mechanisms); database storage structure (file organization, index, hash technology, etc.). Then, on the basis of programming language and database management system, students practice on computers. Only through personal practice, can they have a deeper understanding of theoretical knowledge, constantly discover and study problems in the process of practice, and finally solve problems. Only through this process, students really have the ability to develop database application system.

\section{Design of Teaching Methods and Means of "Database System"}

\subsection{Teaching Methods of "Database System"}

Case teaching is a teaching method which uses basic selected examples to promote students' independent learning. Case teaching method is a comprehensive teaching method. Its purpose is to cultivate students' ability to solve practical problems with the knowledge they have learned. Its main characteristic is the combination of theory and practice. It enables students to constantly summarize in practice in order to improve. The case teaching method conforms to the cognitive law of people. It lays emphasis on the cultivation of students' innovation ability and ability to solve practical problems. In addition, it can guide students to master the corresponding knowledge and skills step by step. Accordingly, the quality and result of teaching can be greatly increased (Zeng \& Zhu, 2017).

\section{1) Case Selection}

The case serves the teaching goal, so it should be typical and directly related to the corresponding theoretical knowledge. But it must have been thoroughly investigated and comes from practice. It should never be conjectured or fabricated by teachers. The case must pay attention to the real details, so that students have a sense of reality, seriously treat the situation in the case, and analyze a variety of data and complex structure. Then, it is possible to search for knowledge, enlightenment wisdom, training ability. For example, teachers can choose the book management system and online bookstore system that students are familiar with or specific enterprise projects that the teacher has personally done as a case.

\section{2) Case Discussion}

Case discussion is the key to the successful implementation of case teaching 
method in database courses and it is also a good teacher-student interaction link. In this process, the case is first decomposed into specific modules. Then teachers and students discuss the relevant knowledge of each module, and analyze the key points and difficulties of this case together finally. Through this process, students have a deep understanding of the case discussed, understand the function of each part, and make a preparation for their own practice database in the future. Therefore, this is a very important link. So, this is a very important link. Teachers must carefully make plans considering the possible situation in the teaching process, the whole teaching time, teaching content, teaching transition and teaching methods.

\section{3) New Case Practice}

After the case discussion stage, students have a clear understanding of the implementation of the database, the next link is the process of students to practice new cases on the computer, which is the most important link. Database system course has a strong practical and applied. So only by hands-on practice of a specific database system, can students truly grasp the basic knowledge of relational database and related programming language, and truly understand the database system. Teachers should leave students enough operating time, make the student bold to try and operate, and enable them to experience, feel and comprehend in practice.

\section{4) Practical Summary}

After case discussion and computer practice, it is the last step and a necessary link of case teaching method to summarize and evaluate the cases in time. Teachers should make a comprehensive evaluation from the proposal, analysis of the case and the design and implementation of the scheme to the final solution of the problem. The evaluation focuses on correctness of the thinking of the case discussion, the appropriateness of the analysis method and the feasibility of the measures. Moreover, it is more important for students to summarize the problems encountered in the database practice and the solutions. Students should also make a summary in written form, so that students can have a deeper understanding of the cases and the problems emerged in the cases.

\subsection{Teaching Means of "Database System"}

\section{1) Encourage students to engage in exploratory learning}

In the process of teaching the database, teachers should encourage students to carry out exploratory learning. Teachers propose questions first in order to stimulate the curiosity of students. Then students may want to explore the problem and solve the problem. But relying on their own original knowledge and skills can make them in confusion. The creation of doubt situation can run through the whole teaching process, everywhere can be doubt. In this way, it is emotionally attractive and always arouses students' curiosity, attention and thirst for knowledge. Students' thinking is in a positive and active state. They can use their brains to create inspiration and insight, and try to explore various ways to solve problems, so that they can learn knowledge and improve their abilities. For ex- 
ample, a teacher can set a final task and break it down into small tasks. Solving the final task by letting students complete one small task after another. By this means, the database course will be vivid, and students will be interested in it. The key challenge in teaching will be solved.

\section{2) Encourage Students to Innovate}

In the teaching process of database course, it is extremely important to cultivate students' innovative spirit. In the teaching process, students should be the main body, and teachers should play the role of organizing, guiding, helping and promoting. Make full use of the situation, collaboration, conversation and other elements to give full play to the initiative and enthusiasm of students. Encourage students to make innovations and use various knowledge to form their own characteristics in the process of student database. With the continuous development of computer security problems, for instance, the content of the database security applied to the development of the system, user friendly interface reasonable and convenient to operate improve the system performance with its own characteristics. It enables students to form the ability of comprehensive use of knowledge and innovative quality.

\section{Conclusion}

In this paper, the teaching mode of "database system" is constructed from the level of teachers and students guided by pragmatism educational thought and taking case teaching method as the basic teaching method. This paper puts forward a reasonable model of database system support system and expounds the specific teaching methods and means. The practice shows that this teaching method is feasible and has achieved remarkable results. With the continuous development of database technology, we still need to continue to study and summarize the teaching experience, so as to make the whole teaching link more perfect and reasonable.

\section{Acknowledgements}

The authors thank the referee for his enlightening and revealing comments to our manuscript. This work was supported in part by NSFC under Grant No. 61941302 and 61702139.

\section{Conflicts of Interest}

The authors declare no conflicts of interest regarding the publication of this paper.

\section{References}

Li, P. (2017). Research on Task Driven Teaching Model Based on Flipped Classroom-Take the "Database Principles" Course as an Example. In 7th International Conference on Management, Education, Information and Control (MEICI 2017). Atlantis Press.

Li, Y. Z. (2016). Application and Exploration of Action-Oriented Teaching Method in Database Teaching. Reading Digest, 3, 153. 
Qian, W., \& Wu, X. L. (2016). Research and Discussion on Non-Computer Major Database Course Teaching in Colleges and Universities. Quality Education in West China, 15, 53-54.

Wan, C. (2016). Discussion on Application of Case Teaching Method in the Course of Database Principles and Applications. China Training, 18, 202-202.

Wang, S., \& Sa, S. X. (2018). Introduction to Database System (5th ed.). Beijing: Higher Education Press.

Wu, G. D. (2016). Discussion on Task-Driven Method in Teaching Practice of Access Database. Research on Curriculum Education: New Teacher Teaching, 31, 129-130.

Zeng, F., \& Zhu, C. (2017). Application of Case Teaching Method in Finance and Economics Course Teaching. Financial Theory and Teaching, 6, 102-104. 